\title{
PROBLEMATIKA HUKUM KAMPANYE PEMILIHAN WALIKOTA DAN WAKIL WALIKOTA BLITAR TAHUN 2015
}

\author{
Sholahuddin Fathurrahman', Ardian Prabowo ${ }^{2}$ \\ 1. Universitas Islam Kadiri, \\ 2. Komisi Pemilihan Umum (KPU) Kota Blitar \\ email:ardian.prabowo@gmail.com
}

\begin{abstract}
ABSTRAK
Tujuan penelitian mengidentifikasi penyebab maupun implikasi hukum pelanggaran kampanye Pemilihan Walikota dan Wakil Walikota Blitar Tahun 2015. Metode penelitian adalah yuridis normatif. Pelanggaran kampanye yang terjadi yaitu, pasangan calon dan/atau tim kampanye mencetak dan memasang alat peraga kampanye, pemasangan alat peraga kampanye tanpa mempertimbangkan etika, estetika, kebersihan dan keindahan kota, serta pemasangan alat peraga kampanye pada lembaga pendidikan.

Penyebab terjadinya pelanggaran dalam pelaksanaan kampanye Pemilihan Walikota dan Wakil Walikota Blitar Tahun 2015, antara lain Pasangan Calon dan/atau Tim Kampanye kurang mentaati Peraturan Komisi Pemilihan Umum Nomor 7 Tahun 2015 dan juga kurangnya sosialisasi peraturan yang berkaitan dengan pelaksanaan kampanye.

Implikasi hukum terhadap pelanggaran atas larangan ketentuan pemasangan Alat Peraga Kampanye dikenai sanksi sebagaimana diatur pada Peraturan Komisi Pemilihan Umum Nomor 7 Tahun 2015, pasal 72.

Kesimpulannya, pelaksanaan kampanye pada Pemilihan Walikota dan Wakil Walikota Blitar Tahun 2015 belum sesuai sebagaimana yang diatur dalam Peraturan Komisi Pemilihan Umum Nomor 7 Tahun 2015.
\end{abstract}

Kata Kunci : Pelanggaran Kampanye, Pemilihan Walikota dan Wakil Walikota Blitar 2015.

\section{A. PENDAHULUAN}

Pemilihan gubernur, bupati dan/atau walikota yang dilakukan secara serentak pada tahun 2015 untuk memilih gubernur, bupati dan/atau walikota yang berlangsung di seluruh wilayah Indonesia merupakan event politik yang cukup menarik perhatian khalayak. Banyak hal layak disorot atas pelaksanaan perhelatan politik lima tahunan tersebut, di antaranya berkaitan dengan masalah kampanye.

Nah, mengingat Peraturan Peraturan Komisi Pemilihan Umum Nomor 7 Tahun 2015 ini merupakan salah satu produk hukum yang dapat disebut relatif baru disusun dan diberlakukan bersamaan dengan proses awal pelaksanan tahapan Pemilihan gubernur, bupati dan/atau walikota serentak Tahun 2015, maka dapat diperkirakan bahwa sosialisasinya belumlah optimal sehingga masih dijumpai kecenderungan pelanggaran atas aturan tersebut.

\section{B. METODE PENELITIAN Jenis Penelitian \\ Dalam tesis ini peneliti menggunakan penelitian lapangan (field}

research) yaitu metode penelitian mengambil obyek penelitian Peraturan Komisi Pemilihan Umum Nomor 7 Tahun 2015 tentang Kampanye Pemilihan Gubernur dan Wakil Gubernur, Bupati dan Wakil Bupati dan/atau Walikota dan Wakil Walikota, apakah sudah sesuai diterapkan atau belum. Dalam hal ini selanjutnya peneliti akan mengkaji lebih mendalam terkait masalah yang diteliti dari data yang sudah ada.

\section{Sifat Penelitian}

Penelitian ini menggunakan pendekatan yuridis normatif, yaitu penelitian yang dilakukan secara langsung kepada narasumber dengan mendasarkan pada data primer sebagai data utamanya.

\section{Teknik Pengumpulan Data}

Pada penelitian ini dilakukan dengan alat dan teknik sebagai berikut:

1. Teknik yang digunakan dalam penelitian ini, yakni dengan teknik wawancara (interview), yaitu mengajukan pertanyaan yang terarah secara langsung kepada subyek penelitian, dalam hal ini Komisi Pemilihan Umum Kota Blitar, Panitia Pengawas Pemilihan Kota Blitar, dan Pasangan Calon/ Tim Kampanye. 
2. Observasi, yaitu suatu pengamatan yang khusus serta pencatatan yang sistematis yang ditujukan pada satu atau beberapa fase masalah dalam rangka penelitian, dengan maksud untuk mendapatkan data yang diperlukan untuk memecahkan masalah yang dihadapi.

3. Dokumentasi yaitu pengumpulan datadata dan bahan-bahan berupa dokumen. Data-data tersebut diperoleh dari Komisi Pemilihan Umum Kota Blitar dan Panitia Pengawas Pemilihan Kota Blitar.

4. Selain itu juga menggunakan studi pustaka, yaitu data yang diperoleh dari buku-buku kepustakaan, peraturan perundang-undangan, internet dan dokumen lainnya yang berhubungan dengan obyek penelitian, dalam hal ini kampanye Pemilihan Walikota dan Wakil Walikota Blitar Tahun 2015 ditinjau dari Peraturan Komisi Pemilihan Umum Nomor 7 Tahun 2015 tentang Kampanye Pemilihan Gubernur dan Wakil Gubernur, Bupati dan Wakil Bupati dan/atau Walikota dan Wakil Walikota.

5. Penelitian lapangan, metode ini digunakan peneliti untuk mengumpulkan data dengan turun langsung kepada pihak yang bersangkutan, yaitu Komisi Pemilihan Umum Kota Blitar dan Panitia Pengawas Pemilihan Kota Blitar.

\section{Sumber Penelitian}

\section{Data Primer}

Data ini diperoleh dari hasil penelitian di lapangan yang berupa hasil wawancara dan data yang diperoleh dari lembaga terkait, yaitu Komisi Pemilihan Umum Kota Blitar, Panitia Pengawas Pemilihan Kota Blitar, dan Pasangan Calon/ Tim Kampanye.

2. Data Sekunder

Data ini diperoleh dari penelitian kepustakaan yang berupa bahan-bahan hukum yang terdiri dari:

A. Bahan Hukum Primer

Bahan hukum primer, yaitu bahan yang memiliki kekuatan mengikat yang berkaitan dengan obyek penelitiam, yakni:

1) Undang-Undang Dasar 1945.
2) Undang-Undang Nomor 15

Tahun 2011 tentang

Penyelenggara Pemilihan Umum.

3) Undang-Undang Nomor 8 Tahun 2015 tentang perubahan atas Undang-Undang Nomor 1 Tahun 2015 tentang Penetapan Peraturan Pemerintah Pengganti Undang-Undang Republik Indonesia Nomor 1 Tahun 2014 tentang Pemilihan Gubernur, Bupati dan Walikota menjadi Undang-Undang.

4) Peraturan Pemerintah Nomor 78 Tahun 2012 tentang perubahan keempat atas Peraturan Pemerintah Nomor 6 Tahun 2005 tentang Pemilihan, Pengesahan Pengangkatan, dan Pemberhentian Kepala Daerah dan Wakil Kepala Daerah.

5) Peraturan Komisi Pemilihan Umum Nomor 2 Tahun 2015 tentang Tahapan, Program dan Jadwal Penyelenggaraan Pemilihan Gubernur dan Wakil Gubernur, Bupati dan Wakil Bupati, dan/atau Walikota dan Wakil Walikota.

6) Peraturan Komisi Pemilihan Umum Nomor 7 Tahun 2015 tentang Kampanye Pemilihan Gubernur dan Wakil Gubernur, Bupati dan Wakil Bupati, dan/atau Walikota dan Wakil Walikota.

B. Bahan Hukum Sekunder.

Bahan hukum sekunder, yaitu bahan yang memberikan penjelasan mengenai bahan hukum primer, misalnya:

1) Buku-buku literatur yang berkaitan dengan permasalahan yang diteliti.

2) Hasil-hasil penelitian para pakar hukum yang berkaitan dengan permasalahan yang diteliti.

C. Bahan Hukum Tersier

Bahan hukum tersier, yaitu bahan hukum yang memberikan petunjuk maupun penjelasan terhadap bahan hukum primer dan sekunder, yang terdiri dari:

1) Kamus Hukum. 


\section{Analisis Data}

2) Kamus Bahasa Indonesia.

Dalam mengelola dan menganalisis data yang diperoleh selama penelitian menggunakan analisis kualitatif, yaitu metode analisis data yang mengelompokkan dan menyeleksi data yang diperoleh dari penelitian lapangan menurut kualitas dan kebenarannya. ${ }^{13}$ Setelah data tersebut terkumpul maka dilakukan analisis. Metode yang dipakai dalam menganalisa dalam penelitian ini menggunakan analisis data dengan penalaran deduktif. ${ }^{14}$ Deduktif merupakan langkah analisis data dengan cara menerangkan data yang bersifat umum untuk membentuk suatu pandangan yang bersifat khusus, sehingga dapat ditarik kesimpulan.

\section{PEMBAHASAN}

Pelanggaran Kampanye Pemilihan

\section{Walikota dan Wakil Walikota Blitar 2015}

1. Ditemukan alat peraga kampanye pasangan calon Walikota dan Wakil Walikota Blitar yang bukan dicetak oleh KPU Kota Blitar, yaitu 2 buah spanduk (lokasi di perempatan Kampus PGSD dan di Jl. Anjasmoro, perempatan Toko Limolas) dan 1 buah bendera. Berdasarkan temuan Panwaslih Kota Blitar Nomor: 06/TM/PILWALI/BLT/SEPTEMBER /2015 tanggal 15 September 2015.

Hal tersebut merupakan pelanggaran terhadap Peraturan Komisi Pemilihan Umum Nomor 7 Tahun 2015 tentang Kampanye Pemilihan Gubernur dan Wakil Gubernur, Bupati dan Wakil Bupati dan/atau Walikota dan Wakil Walikota pasal 68 ayat 2, bahwa pasangan calon dan/atau tim kampanye dilarang mencetak dan memasang alat peraga kampanye selain pada tempat yang telah ditentukan.

2. Ditemukan alat peraga kampanye pasangan calon Walikota dan Wakil Walikota Blitar sebanyak 2 buah spanduk yang diikat di tiang listrik. Berdasarkan temuan Panwaslih Kota Blitar Nomor: 07/TM/PILWALI/BLT/SEPTEMBER /2015 tanggal 25 September 2015.

Hal tersebut merupakan pelanggaran terhadap Peraturan Komisi Pemilihan Umum Nomor 7 Tahun 2015 tentang Kampanye Pemilihan Gubernur dan
Wakil Gubernur, Bupati dan Wakil Bupati dan/atau Walikota dan Wakil Walikota pasal 30 ayat 4, bahwa pemasangan alat peraga kampanye dilaksanakan dengan mempertimbangkan etika, estetika, kebersihan dan keindahan kota atau kawasan setempat sesuai dengan ketentuan peraturan perundangundangan.

3. Ditemukan spanduk yang bergambarkan foto dari salah satu calon Walikota Blitar di halaman SMP Negeri 4 Blitar, SMP Negeri 5 Blitar, dan SMP Negeri 6 Blitar, yang berisikan memperingati Hari Lahirnya Pancasila. Berdasarkan temuan Panwaslih Kota Blitar Nomor: 08/TM/PILWALI/BLT/SEPTEMBER /2015 tanggal 28 September 2015.

Hal tersebut merupakan Pelanggaran terhadap Peraturan Komisi Pemilihan Umum Nomor 7 Tahun 2015 tentang Kampanye Pemilihan Gubernur dan Wakil Gubernur, Bupati dan Wakil Bupati dan/atau Walikota dan Wakil Walikota pasal 30 ayat 3, bahwa lokasi pemasangan alat peraga kampanye dilarang berada di:

a.) Tempat ibadah termasuk halaman.

b.) Rumah sakit atau tempat pelayanan kesehatan.

c.) Gedung milik pemerintah.

d.) Lembaga pendidikan (gedung dan sekolah).

4. Ditemukan alat peraga kampanye pasangan calon Walikota dan Wakil Walikota Blitar yang bukan dicetak oleh KPU Kota Blitar, yaitu 1 buah bando. Berdasarkan temuan Panwaslih Kota Blitar Nomor: 10/TM/PILWALI/BLT/OKTOBER/2 015 tanggal 15 Oktober 2015.

Hal tersebut merupakan pelanggaran terhadap Peraturan Komisi Pemilihan Umum Nomor 7 Tahun 2015 tentang Kampanye Pemilihan Gubernur dan Wakil Gubernur, Bupati dan Wakil Bupati dan/atau Walikota dan Wakil Walikota pasal 68 ayat 2, bahwa pasangan calon dan/atau tim kampanye dilarang mencetak dan memasang alat peraga kampanye selain pada tempat yang telah ditentukan. 


\section{Penyebab Pelanggaran Kampanye Pemilihan Walikota dan Wakil Walikota Blitar Tahun 2015}

Pasangan Calon dan/atau Tim Kampanye mengartikan pemilu sebagai pesta demokrasi itu harus dimeriahkan dengan banyak memasang alat peraga kampanye. Pasangan Calon dan/atau Tim Kampanye kurang memiliki kesadaran untuk mentaati dan mencermati isi atau substansi dari peraturan Komisi Pemilihan Umum Nomor 7 Tahun 2015. Pasangan Calon dan/atau Tim Kampanye juga kurang mengoptimalkan pengawasan internal kepada anggotanya dalam pemasangan alat peraga kampanye. Selain itu, tidak adanya kesadaran atau inisiatif Pasangan Calon dan/atau Tim Kampanye untuk membersihkan alat peraga kampanye miliknya sendiri yang dipasang tidak sesuai Peraturan Komisi Pemilihan Umum Nomor 7 Tahun 2015.

Kurangnya jumlah personil Panwaslih Kota Blitar, maupun koordinasi antara panwaslih, panwascam dan panitia pengawas lapangan dalam mendampingi, mengawasi, serta menertibkan alat peraga kampanye. Kurang adanya sosialisasi kepada instansi Pemerintah Kota Blitar yang berhubungan langsung dengan tugas Panwaslih Kota Blitar untuk mengetahui peran dan tugas masing-masing, sehingga terdapat perbedaan pandangan mengenai penertiban alat peraga kampanye yang dipahami oleh Satpol PP Kota Blitar dan jajarannya. Sehingga Satpol PP Kota Blitar selaku pemelihara ketertiban umum kurang mengawasi secara langsung pemasangan alat peraga yang dilakukan oleh Pasangan Calon dan/atau Tim Kampanye maupun mencabut alat peraga kampanye yang tidak sesuai dengan peraturan agar tidak merusak keindahan Kota Blitar. Selain itu juga kurang adanya sosialisasi kepada masyarakat tentang apa dan bagaimana pemasangan alat peraga kampanye yang benar, sehingga masyarakat kurang ikut serta mengawasi dan melaporkan kepada Panwaslih Kota Blitar tentang adanya pelanggaran pemasangan alat peraga kampanye.

KPU Kota Blitar beserta jajarannya hingga PPK dan PPS kurang mensosialisasikan peraturan-peraturan yang berkaitan dengan pelaksanaan kampanye dengan baik dan lebih maksimal, sehingga
Pasangan Calon dan/atau Tim Kampanye kurang memahami dan melakukan pelanggaran dengan alasan tidak tahu aturannya. Regulasi yang ada juga kurang dilengkapi dengan sanksi-sanksi terhadap pelanggaran yang benar-benar dapat memberikan efek jera kepada Pasangan Calon dan/atau Tim Kampanye.

\section{Implikasi Hukum Pelanggaran Kampanye Pemilihan Walikota dan Wakil Walikota Blitar Tahun 2015}

Sebagaimana diatur pada Peraturan Komisi Pemilihan Umum Nomor 7 Tahun 2015 tentang Kampanye Pemilihan Gubernur dan Wakil Gubernur, Bupati dan Wakil Bupati, dan/atau Walikota dan Wakil Walikota, pasal 72 disebutkan bahwa pelanggaran atas larangan ketentuan pemasangan Alat Peraga Kampanye dikenai sanksi:

1. peringatan tertulis;

2. perintah penurunan Alat Peraga Kampanye dalam waktu 1 × 24 (satu kali dua puluh empat) jam.

3. Apabila Pasangan Calon tidak melaksanakan ketentuan, Bawaslu Provinsi, Panwas Kabupaten/Kota, dan/atau Panwas Kecamatan berkoordinasi dengan Satuan Polisi Pamong Praja setempat untuk menurunkan Alat Peraga Kampanye.

Pelanggaran kampanye Pemilihan Walikota dan Wakil Walikota Blitar Tahun 2015 serta implikasi hukumnya, diantaranya sebagai berikut:

1. Ditemukan alat peraga kampanye pasangan calon Walikota dan Wakil Walikota Blitar yang bukan dicetak oleh KPU Kota Blitar, yaitu 2 buah spanduk (lokasi di perempatan Kampus PGSD dan di Jl. Anjasmoro, perempatan Toko Limolas) dan 1 buah bendera. Berdasarkan temuan Panwaslih Kota Blitar Nomor: 06/TM/PILWALI/BLT/SEPTEMBER /2015 tanggal 15 September 2015.

Hal tersebut merupakan pelanggaran terhadap Peraturan Komisi Pemilihan Umum Nomor 7 Tahun 2015 tentang Kampanye Pemilihan Gubernur dan Wakil Gubernur, Bupati dan Wakil Bupati dan/atau Walikota dan Wakil Walikota pasal 68 ayat 2, bahwa pasangan calon dan/atau tim kampanye 
dilarang mencetak dan memasang alat peraga kampanye selain pada tempat yang telah ditentukan.

$$
\text { Implikasi hukumnya adalah, }
$$

Panwaslih Kota Blitar merekomendasikan kepada KPU Kota Blitar melalui Surat Nomor: $\quad 03 / R E K O M / P A N W A S-$ KOTA/BLT/IX/2015. Kemudian ada penyampaian hasil tindak lanjut rekomendasi dari KPU Kota Blitar melalui Surat Nomor: 680/KPU.Kota-014.329960/IX/2015 yang menyatakan bahwa dalam penyelesaian pelanggaran administrasi belum ada peraturan Komisi Pemilihan Umum yang mengaturnya sehingga bukan menjadi tanggung jawab KPU Kota Blitar. Selanjutnya Panwaslih Kota Blitar berkoordinasi dengan Satpol PP Kota Blitar untuk mentertibkan alat peraga kampanye dimaksud, melalui Surat Nomor: 215.1/PANWAS-KOTA/BLT/IX/2015 tanggal 28 September 2015. Selain itu, Panwaslih Kota Blitar juga mengundang KPU Kota Blitar untuk melakukan konfirmasi pada tanggal 2 Oktober 2015 pukul. 09.00 - 11.00 WIB bertempat di Aula Kantor Panwaslih Kota Blitar. Dari hasil pengawasan terakhir didapatkan bahwa alat peraga kampanye tersebut sudah ditertibkan.

2. Ditemukan alat peraga kampanye pasangan calon Walikota dan Wakil Walikota Blitar sebanyak 2 buah spanduk yang diikat di tiang listrik. Berdasarkan temuan Panwaslih Kota Blitar Nomor: 07/TM/PILWALI/BLT/SEPTEMBER /2015 tanggal 25 September 2015.

Hal tersebut merupakan pelanggaran terhadap Peraturan Komisi Pemilihan Umum Nomor 7 Tahun 2015 tentang Kampanye Pemilihan Gubernur dan Wakil Gubernur, Bupati dan Wakil Bupati dan/atau Walikota dan Wakil Walikota pasal 30 ayat 4, bahwa pemasangan alat peraga kampanye dilaksanakan dengan mempertimbangkan etika, estetika, kebersihan dan keindahan kota atau kawasan setempat sesuai dengan ketentuan peraturan perundang-undangan.

$$
\text { Implikasi hukumnya adalah, }
$$

Panwaslih Kota Blitar merekomendasikan kepada KPU Kota Blitar melalui Surat Nomor: $\quad 04 / R E K O M / P A N W A S-$ KOTA/BLT/IX/2015. Kemudian ada penyampaian hasil tindak lanjut rekomendasi dari KPU Kota Blitar melalui Surat Nomor: 681/KPU.Kota-014.329960/IX/2015 yang menyatakan bahwa pemasangan alat peraga kampanye dimaksud akan diperbaiki. Dari hasil pengawasan terakhir didapatkan bahwa alat peraga kampanye tersebut sudah dipindahkan.

3. Ditemukan spanduk yang bergambarkan foto dari salah satu calon Walikota Blitar di halaman SMP Negeri 4 Blitar, SMP Negeri 5 Blitar, dan SMP Negeri 6 Blitar, yang berisikan memperingati Hari Lahirnya Pancasila. Berdasarkan temuan Panwaslih Kota Blitar Nomor: 08/TM/PILWALI/BLT/SEPTEMBER /2015 tanggal 28 September 2015.

Hal tersebut merupakan Pelanggaran terhadap Peraturan Komisi Pemilihan Umum Nomor 7 Tahun 2015 tentang Kampanye Pemilihan Gubernur dan Wakil Gubernur, Bupati dan Wakil Bupati dan/atau Walikota dan Wakil Walikota pasal 30 ayat 3, bahwa lokasi pemasangan alat peraga kampanye dilarang berada di:

a.) Tempat ibadah termasuk halaman.

b.) Rumah sakit atau tempat pelayanan kesehatan.

c.) Gedung milik pemerintah.

d.) Lembaga pendidikan (gedung dan sekolah).

Implikasi hukumnya adalah, Panwaslih Kota Blitar memberikan himbauan kepada Dinas Pendidikan Kota Blitar melalui Surat Nomor: 215/PANWASKOTA/BLT/IX/2015 yang isinya menghimbau kepada Dinas Pendidikan Kota Blitar untuk menginstruksikan kepada para Kepala Sekolah se-Kota Blitar untuk tidak memasang alat peraga kampanye dan untuk yang sudah terlanjur terpasang agar segera diturunkan. Dari hasil pengawasan terakhir didapatkan bahwa alat peraga kampanye tersebut sudah diturunkan oleh pihak sekolah yang bersangkutan.

4. Ditemukan alat peraga kampanye pasangan calon Walikota dan Wakil Walikota Blitar yang bukan dicetak oleh KPU Kota Blitar, yaitu 1 buah bando. Berdasarkan temuan Panwaslih Kota Blitar Nomor: 10/TM/PILWALI/BLT/OKTOBER/2 015 tanggal 15 Oktober 2015.

Hal tersebut merupakan pelanggaran terhadap Peraturan Komisi Pemilihan Umum Nomor 7 Tahun 2015 tentang Kampanye Pemilihan Gubernur dan Wakil Gubernur, 
Bupati dan Wakil Bupati dan/atau Walikota dan Wakil Walikota pasal 68 ayat 2, bahwa pasangan calon dan/atau tim kampanye dilarang mencetak dan memasang alat peraga kampanye selain pada tempat yang telah ditentukan.

Implikasi hukumnya adalah, Panwaslih Kota Blitar merekomendasikan kepada KPU Kota Blitar melalui Surat Nomor: $\quad$ 07/REKOM/PANWASKOTA/BLT/X/2015. Kemudian ada penyampaian hasil tindak lanjut rekomendasi dari KPU Kota Blitar melalui Surat Nomor: 772/KPU.Kota-014.329960/X/2015 yang menyatakan bahwa KPU Kota Blitar telah melakukan teguran secara lisan kepada tim kampanye Pasangan Calon pada tanggal 15 Oktober 2015 maupun teguran secara tertulis kepada tim kampanye Pasangan Calon pada tanggal 20 Oktober 2015 melalui Surat Nomor: 767/KPU.Kota014.329960/X/2015. Selanjutnya Panwaslih Kota Blitar berkoordinasi dengan Satpol PP Kota Blitar melalui Surat Nomor: 247/PANWAS-KOTA/BLT/X/2015 tertanggal 22 Oktober 2015. Dari hasil pengawasan terakhir didapatkan bahwa alat peraga kampanye tersebut telah diturunkan.

\section{KESIMPULAN}

Sesuai dengan rumusan masalah dan diikuti dengan pembahasan dan analisis dari penyusun dapat disimpulkan bahwa pelaksanaan kampanye pada Pemilihan Walikota dan Wakil Walikota Blitar Tahun 2015 belum sesuai sebagaimana yang diatur dalam Peraturan Komisi Pemilihan Umum Nomor 7 Tahun 2015 tentang Kampanye Pemilihan Gubernur dan Wakil Gubernur, Bupati dan Wakil Bupati, dan/atau Walikota dan Wakil Walikota. Sebab ada beberapa pasal-pasal di dalam Peraturan Komisi Pemilihan Umum tersebut yang diabaikan oleh Pasangan Calon dan/atau Tim Kampanye. Pasal-pasal tersebut diantaranya adalah:

1) Pasal 68 ayat 2, bahwa pasangan calon dan/atau tim kampanye dilarang mencetak dan memasang alat peraga kampanye selain pada tempat yang telah ditentukan.

2) Pasal 30 ayat 4, bahwa pemasangan alat peraga kampanye dilaksanakan dengan mempertimbangkan etika, estetika, kebersihan dan keindahan kota atau kawasan setempat sesuai dengan ketentuan peraturan perundangundangan.

3) Pasal 30 ayat 3, bahwa lokasi pemasangan alat peraga kampanye dilarang berada:

a.) Tempat ibadah termasuk halaman.

b.) Rumah sakit atau tempat pelayanan kesehatan.

c.) Gedung milik pemerintah.

d.) Lembaga pendidikan (gedung dan sekolah).

1. Terdapat beberapa faktor penyebab terjadinya pelanggaran dalam pelaksanaan kampanye Pemilihan Walikota dan Wakil Walikota Blitar Tahun 2015, antara lain sebagai berikut:

a. Pasangan Calon dan/atau Tim Kampanye kurang memiliki kesadaran untuk mentaati dan mencermati isi atau substansi dari Peraturan Komisi Pemilihan Umum Nomor 7 Tahun 2015 tentang Kampanye Pemilihan Gubernur dan Wakil Gubernur, Bupati dan Wakil Bupati, dan/atau Walikota dan Wakil Walikota.

b. Panwaslih Kota Blitar kurang mensosialisasikan kepada Satpol PP Kota Blitar selaku pemelihara ketertiban umum maupun kepada masyarakat, sehingga mereka kurang ikut serta mengawasi maupun melaporkan kepada Panwaslih Kota Blitar tentang adanya pelanggaran pemasangan alat peraga kampanye.

c. KPU Kota Blitar kurang mensosialisasikan peraturanperaturan yang berkaitan dengan pelaksanaan kampanye dengan baik dan lebih maksimal, sehingga Pasangan Calon dan/atau Tim Kampanye kurang memahami dan melakukan pelanggaran dengan alasan tidak tahu aturannya.

d. Regulasi yang ada juga kurang dilengkapi dengan sanksi-sanksi terhadap pelanggaran yang benarbenar dapat memberikan efek jera kepada Pasangan Calon dan/atau Tim Kampanye. 
2. Implikasi hukum terhadap pelanggaran atas larangan ketentuan pemasangan Alat Peraga Kampanye dikenai sanksi sebagaimana diatur pada Peraturan Komisi Pemilihan Umum Nomor 7 Tahun 2015 tentang Kampanye Pemilihan Gubernur dan Wakil Gubernur, Bupati dan Wakil Bupati, dan/atau Walikota dan Wakil Walikota, pasal 72 yaitu:

a. peringatan tertulis;

b. perintah penurunan Alat Peraga Kampanye dalam waktu 1 x 24 (satu kali dua puluh empat) jam.

c. Apabila Pasangan Calon dan/atau Tim Kampanye tidak melaksanakan ketentuan, Panwaslih Kota Blitar, dan/atau Panwas Kecamatan berkoordinasi dengan Satuan Polisi Pamong Praja Kota Blitar untuk menurunkan Alat Peraga Kampanye.

Penindakan terhadap pelanggaran pemasangan alat peraga kampanye tidak saja merupakan tanggung jawab dari Panwaslih Kota Blitar sebagai Penyelenggara pemilu yang berwenang untuk mengawasi, namun juga merupakan tanggung jawab dari Pasangan Calon dan/atau Tim Kampanye serta Satpol PP Kota Blitar sebagai eksekutor terhadap alat peraga kampanye yang dianggap telah melanggar peraturan yang ada oleh Panwaslih Kota Blitar.

\section{F. DAFTAR PUSTAKA}

Jimly Asshiddiqie, Hukum Tata Negara dan Pilar-Pilar Demokrasi, Sekjen dan kepaniteraan MK RI, Jakarta: 2006.

Joko J. Prihatmoko, Pemiliban Kepala Daerah Langsung. Pustaka Pelajar, Yogyakarta: 2005.

M. Fuady, Teori Negara Hukum Modern, Refika Aditama, Bandung: 2009.

Umbu Rauta, Bunga Rampai Hukum Tata Negara Indonesia, FH-UKSW, Salatiga: 2000.

Soerjono Soekanto, Penelitian Hukum Normatif, Rajawali Press, Jakarta: 2006.

Sutrisno Hadi, Metodologi Riset, Fakultas Psikologi UGM, Yogyakarta: 1984.
Febry Chrisdanty \& Diah Wahyulina,

Penanganan Pelanggaran Kampanye Pemiliban Umum Anggota DPR, DPD, dan DPRD di Wilayah Kabupaten/Kota, Universitas Wisnuwardhana, Malang: 2014.

Komisi Pemilihan Umum Kota Blitar, Laporan Penyelenggaraan Tahapan Pemiliban Walikota dan Wakil Walikota Blitar Tabun 2015, Blitar: 2015.

Undang-Undang Dasar 1945.

Undang-Undang Nomor 15 Tahun 2011 tentang Penyelenggara Pemilitan Umum.

Undang-Undang Nomor 8 Tahun 2015 tentang perubahan atas UndangUndang Nomor 1 Tahun 2015 tentang Penetapan Peraturan Pemerintah Pengganti UndangUndang Republik Indonesia Nomor 1 Tahun 2014 tentang Pemiliban Gubernur, Bupati dan Walikota menjadi Undang-Undang.

Peraturan Pemerintah Nomor 78 Tahun 2012 tentang perubahan keempat atas Peraturan Pemerintah Nomor 6 Tahun 2005 tentang Pemiliban, Pengesaban Pengangkatan, dan Pemberhentian Kepala Daerah dan Wakil Kepala Daerah.

Peraturan Komisi Pemilihan Umum Nomor 2 Tahun 2015 tentang Tabapan, Program dan Jadwal Penyelenggaraan Pemiliban Gubernur dan Wakil Gubernur, Bupati dan Wakil Bupati, dan/atau Walikota dan Wakil Walikota.

Peraturan Komisi Pemilihan Umum Nomor 7 Tahun 2015 tentang Kampanye Pemiliban Gubernur dan Wakil Gubernur, Bupati dan Wakil Bupati, dan/atau Walikota dan Wakil Walikota.

Dian Ramdhani, Pelanggaran Kampanye Pilkada Marak, sindonews.com, 16 September 2015.

Suprapta, Pilkada Serentak 2015; Alat Peraga Kampanye dan Pentingnya Memperbatikan Lingkungan, kompasiana.com, 29 September 2015.

Amril Amarullah, Tujuh Rekomendasi RAKORNAS PDIP, vivanews.com, 6 Agustus 2010. 
Awasi Pemilihan Kepala Daerah dan Wakil Kepala Daerah, Bawaslu gandeng KPK, vivanews.com, 18 Februari 2010.

Pipiet T. N \& Syahrul A, MK: Sistem Pemilihan Kepala Daerah dan Wakil Kepala Daerah Suburkan Money Politics, vivanews.com, 3 Februari 2012.

Arif B. A \& Moh. Adam, Ini Biang Semua Sengketa Pemilu dan Pilkada, vivanews.com, 21 Februari 2012.

Maryadie, Kalah, Enam Kandidat Minta Pilkada Ulang, vivanews.com, 29 Oktober 2008. 